University of Nebraska - Lincoln

DigitalCommons@University of Nebraska - Lincoln

Faculty Papers and Publications in Animal

Science

Animal Science Department

2002

\title{
The Role of Nutrition in Reducing Nutrient Output from Ruminants
}

L. D. Satter

USDA-ARS

Terry J. Klopfenstein

University of Nebraska-Lincoln, tklopfenstein1@unl.edu

Galen E. Erickson

University of Nebraska-Lincoln, gerickson4@unl.edu

Follow this and additional works at: https://digitalcommons.unl.edu/animalscifacpub

Part of the Animal Sciences Commons

Satter, L. D.; Klopfenstein, Terry J.; and Erickson, Galen E., "The Role of Nutrition in Reducing Nutrient Output from Ruminants" (2002). Faculty Papers and Publications in Animal Science. 472.

https://digitalcommons.unl.edu/animalscifacpub/472

This Article is brought to you for free and open access by the Animal Science Department at DigitalCommons@University of Nebraska - Lincoln. It has been accepted for inclusion in Faculty Papers and Publications in Animal Science by an authorized administrator of DigitalCommons@University of Nebraska - Lincoln. 


\title{
The role of nutrition in reducing nutrient output from ruminants ${ }^{1}$
}

\author{
L. D. Satter, ${ }^{2}$ T. J. Klopfenstein $\dagger$, and G. E. Erickson $\dagger$ \\ *U.S. Dairy Forage Research Center, USDA-ARS, Madison, WI 53706 and \\ $\dagger$ Department of Animal Sciences, University of Nebraska, Lincoln 68583
}

\begin{abstract}
Much of the effort expended on nutrient management has focused on the post-excretion product. It is important to keep in mind that management of the diet can have important impacts on quantitative and qualitative aspects of the excreted nutrients. Surveys of nutritionists and extension specialists show that dairy producers are advised to feed 0.45 to $0.50 \%$ phosphorus (P) (DM basis) in their lactating cow diets. This is $20 \%$ in excess of NRC (2001) requirements. Feeding to requirement would reduce $\mathrm{P}$ excretion by 25 to $30 \%$ and would reduce solubility and potential for runoff of the $\mathrm{P}$ that is applied to fields. Nitrogen $(\mathrm{N})$ excretion by dairy cows can also be decreased, but by a lesser amount. Balancing ruminally undegraded and degraded protein and use of protected methionine along with strategic selection of protein supplements that are relatively rich in lysine, may permit a 10 to $15 \%$ reduction in total $\mathrm{N}$ excretion, with most of the reduction occurring in urinary N. Urinary urea, following conversion to ammonia, is the $\mathrm{N}$ excretion product most vulnerable for loss to the environment. Feedlot cattle rou-
\end{abstract}

tinely consume P in excess of NRC (1996) predicted requirements, and recent research suggests the NRC estimates of the $\mathrm{P}$ requirements are high. Decreasing dietary $\mathrm{P}$ from the industry average $(0.35 \% \mathrm{P})$ to the NRC predicted requirement (0.22 to $0.28 \%$ ) decreased $\mathrm{P}$ input by 33 to $45 \%$ and excretion by 40 to $50 \%$ in nutrient balance studies. With grain-based feedlot diets, overfeeding $\mathrm{P}$ is inevitable. At minimum, supplemental $\mathrm{P}$ sources should be removed from diet formulations. More accurate formulation of feedlot diets for protein provides opportunity for reducing $\mathrm{N}$ excretion. By using the NRC model for metabolizable protein, and by employing phase-feeding, $\mathrm{N}$ inputs may be decreased by 10 to $20 \%$ from the feedlot industry average of $13.5 \%$ dietary CP. This translates into a 12 to $21 \%$ reduction in $\mathrm{N}$ excretion, and 15 to $33 \%$ reduction in ammonia volatilization in open-dirt feedlot pens. Diet formulation can have an important impact on the amount of $\mathrm{N}$ and $\mathrm{P}$ excreted in both dairy and beef. It is much easier to control potential pollutants by managing their release into the environment than to recover or confine them once they are released.

Key Words: Cattle Manure, Dairy Wastes, Feedlot Wastes, Nitrogen, Phosphorus, Ruminants

(C2002 American Society of Animal Science. All rights reserved.

J. Anim. Sci. 80(E. Suppl. 2):E143-E156

\section{Introduction}

Public scrutiny of the impact of agricultural practices on the environment is growing. The livestock and poultry industries have been targeted for attention because of their visibility, and for real as well as perceived abuses. Large concentrations of animals in relatively small areas create difficult challenges in terms of odor and nutrient management, but problems of nutrient

\footnotetext{
${ }^{1}$ Trade names and the names of commercial companies are used in this report to provide specific information. Mention of a trade name or manufacturer does not constitute a guarantee or warranty of the product by the USDA or University of Nebraska or an endorsement over products not mentioned.

${ }^{2}$ Correspondence: 1925 Linden Drive West (phone: 608-264-5353; fax: 608-264-5147; E-mail: lsatter@dfrc.wisc.edu).

Received July 26, 2001.

Accepted May 16, 2002..
}

management can plague small as well as large animal operations. One of the fundamental challenges facing the livestock/feed industries is to recycle the flow of feed nutrients, particularly nitrogen $(\mathrm{N})$ and phosphorus $(\mathrm{P})$ from animal manure back to cropland where they can again be used for crop production. Anything short of this is not sustainable, and will ultimately be unacceptable to the broader public.

Many aspects of this fundamental challenge involve manure management and application methods to cropland, and are beyond the scope of this paper. There is an important role for nutrition, however, because dietary content of $\mathrm{N}$ and $\mathrm{P}$ has a direct effect on the quantity of $\mathrm{N}$ and $\mathrm{P}$ excreted in manure. To achieve effective nutrient recycling, and to minimize environmental damage, application of manure nutrients must be limited to an amount that crops can utilize. Areas with high livestock densities will have to transport manure nutrients over longer distances to avoid overappli- 
cation of nutrients, or alternatively, to relocate animals to where cropland is available for manure application. Feeding less $\mathrm{N}$ and $\mathrm{P}$, to the extent possible, will reduce the land area required for manure application.

The objective of this paper is to review protein and phosphorus nutrition of lactating dairy cows and feedlot beef animals, with a view to decreasing the environmental impact of $\mathrm{N}$ and $\mathrm{P}$ in dairy and feedlot manure.

\section{Impact of dietary protein on nitrogen output in manure}

Discussion will be limited to $\mathrm{N}$ and $\mathrm{P}$ in dairy and beef feedlot situations. Seldom are $\mathrm{N}$ and $\mathrm{P}$ of environmental concern in extensive grazing operations. Also, an excellent review on $\mathrm{P}$ nutrition of grazing beef cattle is available (Karn, 2001). Excess N can lead to nitrate contamination of groundwater and release of ammonia and nitrous oxide to the atmosphere, resulting in acid rain and formation of small particles in the atmosphere. Phosphorus can be transported with eroded soil particles or solubilized in surface runoff, fertilizing surface waters and hastening eutrophication of lakes and streams.

Most proteins are highly digestible in the ruminant gastrointestinal tract, and true digestibility is usually in excess of $80 \%$. Undigested protein is excreted in the feces, while the digested protein is either converted into animal tissue or milk protein, or converted to urea in the liver and excreted as urea by the kidney. Some of the urea is recycled back into the gastrointestinal tract and incorporated into gut microbes. Subsequently, some of the $\mathrm{N}$ incorporated into gut microbes is excreted in feces as microbial residue. The amount as well as the route of $\mathrm{N}$ excretion can have an important effect on the environmental impact of manure $\mathrm{N}$.

\section{Dairy Cattle}

It goes without saying that reducing dietary protein to the minimum necessary to meet requirements will minimize excretion of $\mathrm{N}$ in urine and feces. Likewise, increasing milk production so more nutrients are partitioned to product (milk) formation relative to maintenance will have an impact on whether dietary $\mathrm{N}$ ends up in milk or in feces and urine. Clearly, improvements in $\mathrm{N}$ utilization can be made in both diet formulation and in increasing the production level of lactating cows. The ensuing discussion, however, will focus on effect of diet on excretion of $\mathrm{N}$ at a given milk production level.

The relative high cost of protein has provided incentive for dairy producers to avoid excessive protein concentrations in the diet. While overfeeding of protein does occur, it is somewhat less than overfeeding of some other nutrients, such as $\mathrm{P}$.

Kohn et al. (1997) have done a sensitivity analysis of $\mathrm{N}$ losses from dairy farms, and concluded that there is great potential to reduce $\mathrm{N}$ loading by improving herd nutritional efficiency, and by optimizing crop selection to control the source of $\mathrm{N}$ input to the farm and to improve crop nutrient uptake. They further concluded that reducing losses of $\mathrm{N}$ from manure collection, storage and application would be about one-fourth as effective as either improving herd nutritional efficiency or optimizing crop selection.

In order to obtain some estimate of how much impact dietary manipulation of $\mathrm{N}$ can have on total $\mathrm{N}$ excretion, let us examine two situations. Situation A is where high moisture alfalfa silage is the only forage $(55 \%$ of diet DM), high moisture ground corn is the major concentrate ingredient, and the protein supplement is soybean meal, a relatively easily degraded protein source. Using the NRC (2001) model for estimating the protein requirement, $20.8 \% \mathrm{CP}$ is required in the diet for cows producing $40.8 \mathrm{~kg}$ milk/d at $90 \mathrm{~d}$ in lactation. Situation B is again where forage constitutes $55 \%$ of ration $\mathrm{DM}$, but the forage source is $50 \%$ alfalfa hay and $50 \%$ corn silage, dry ground corn is the major concentrate ingredient, and the protein supplement is primarily a mixture of corn distiller's grains, meat and bone meal, blood meal and expeller soybean meal, protein sources with a relatively large proportion of RUP. Using the NRC (2001) model, $15.8 \% \mathrm{CP}$ is required for 40.8 $\mathrm{kg}$ milk/d at $90 \mathrm{~d}$ in lactation with this diet. In both examples, RUP supply was exactly matched with the RUP requirement. In the first example, however, excess RDP was fed in order to meet the RUP requirement.

While there is no assurance that the NRC model is accurately portraying these examples, it does strongly suggest that choosing between all alfalfa silage as the forage or a 50:50 mix of alfalfa silage:corn silage, along with an appropriate choice of protein supplements, can have a large impact on the amount of CP needed in the ration to supply adequate amounts of RUP. The CP in alfalfa silage is largely RDP, reflecting the fact that 50 to $60 \%$ of total $\mathrm{N}$ in alfalfa silage is typically in nonprotein nitrogen form (Luchini et al., 1997). Studies which show that protein is more limiting for milk production than energy when diets high in alfalfa silage content are fed (Dhiman and Satter, 1993; Dhiman et al., 1993) further augment the point that alfalfa silage is a poor source of RUP. Diets high in alfalfa content are difficult to balance for efficient protein utilization.

Wu and Satter (2000) measured milk production response to four different amounts of protein supplementation in a complete lactation study utilizing 58 multiparous cows. Milk N secretion was estimated from milk production and milk composition measurements, and total manure $\mathrm{N}$ calculated as total $\mathrm{N}$ intake minus milk $\mathrm{N}$. The four treatments were as follows, where the first number is the dietary CP content (\% of diet DM) during the first $16 \mathrm{wk}$ of lactation, and the second number is the protein content for wk 17 to 44 of lactation: 15.4 to $16.0,17.4$ to $16.0,17.4$ to 17.9 , and 19.3 to 17.9 . Diets were formulated to maximize the supply of amino acids to the intestine. Alfalfa silage and corn silage (3:2 DM basis) provided the forage. Results are in Table 1. Milk $\mathrm{N}$ as a percentage of intake $\mathrm{N}$ for the complete lactation 
Table 1. Milk yield, intake $\mathrm{N}$, milk $\mathrm{N}$, and manure $\mathrm{N}$ of cows fed diets varying in $\mathrm{CP}$ content during 308-d lactation (Wu and Satter, 2000)

\begin{tabular}{lcccc}
\hline \hline & \multicolumn{4}{c}{ Treatment $^{\mathrm{x}}$} \\
\cline { 2 - 4 } Item & $15.4-16.0$ & $17.4-16.0$ & $17.4-17.9$ & $19.3-17.9$ \\
\cline { 2 - 4 } & \multicolumn{4}{c}{ (kilograms) } \\
\cline { 2 - 5 } $\mathrm{N}$ & 15 & 15 & 14 & 14 \\
Milk yield & $10,056^{\mathrm{c}}$ & $10,832^{\mathrm{b}}$ & $11,095^{\mathrm{a}}$ & $11,132^{\mathrm{a}}$ \\
$3.5 \%$ FCM & $10,690^{\mathrm{b}}$ & $11,628^{\mathrm{a}}$ & $11,804^{\mathrm{a}}$ & $11,559^{\mathrm{a}}$ \\
Intake N & $177.8^{\mathrm{c}}$ & $189.1^{\mathrm{b}}$ & $213.7^{\mathrm{a}}$ & $214.2^{\mathrm{a}}$ \\
Milk N & 51.2 & $48.9^{\mathrm{b}}$ & 51.5 & $53.0^{\mathrm{a}}$ \\
Manure $\mathrm{N}^{\mathrm{y}}$ & $126.6^{\mathrm{c}}$ & $140.2^{\mathrm{b}}$ & $162.2^{\mathrm{a}}$ & $161.2^{\mathrm{a}}$ \\
\hline
\end{tabular}

${ }^{\mathrm{a}, \mathrm{b}, \mathrm{c}}$ Values without superscripts do not $\operatorname{differ}(P>0.15)$ from other values within a row.

${ }^{\mathrm{x}}$ Treatments varying in dietary CP content: $15.4 \%$ during lactation wk 1 to 16 and $16.0 \%$ during wk 17 to 44 (15.4-16.0), 17.4\% during wk 1 to 16 and 16.0\% during wk 17 to 44 (17.4-16.0), 17.4\% during wk 1 to 16 and $17.9 \%$ during wk 17 to 44 (17.4-17.9), and 19.3\% during wk 1 to 16 and $17.9 \%$ during wk $17-44$ (19.3-17.9).

${ }^{\mathrm{y}}$ Calculated from intake $\mathrm{N}-$ milk $\mathrm{N}$, assuming no net deposition or mobilization of tissue $\mathrm{N}$.

was $28.8,25.9,24.1$, and $24.7 \%$ for the four treatments. The low-protein diet was deficient for cows of this production capacity (10,000 to $11,000 \mathrm{~kg}$ milk/308 d). The high-protein diet appeared slightly in excess of requirement. Reducing $\mathrm{N}$ intake by $17 \%$ in this experiment (from high treatment to the low treatment) resulted in a $21 \%$ reduction in manure $\mathrm{N}$, but it also caused a $10 \%$ reduction in milk production.

Three other studies conducted under circumstances similar to this study, but only during early lactation, have been reported (Christensen et al., 1993; Cunningham et al., 1996; Komaragiri and Erdman, 1997). In all cases, relatively high-producing Holstein cows were used, and corn silage, alfalfa, or both provided the forage. Corn was the major grain source, and protein supplements high in RUP were used to raise dietary protein from an average of $16.7 \%$ to an average of $19.6 \% \mathrm{CP}$. Two (Cunningham et al., 1996; Komaragiri and Erdman, 1997) of the three studies reported nonsignificant increases in milk production, while the third study noted a very small, nonsignificant decline in milk production as dietary protein was increased. Taking all four studies into consideration, we conclude that an increase in peak production from feeding more than $17.5 \% \mathrm{CP}$ is possible, but the increase from feeding more than $17.5 \% \mathrm{CP}$ in early lactation to high-producing cows fed corn silage, alfalfa, corn grain, and protein supplements having relatively high RUP values will be marginally profitable at best. Feeding diets with more than $17.5 \% \mathrm{CP}$ in early lactation (assuming diets are similar to what has been herein described) will simply add cost and unwanted amounts of $\mathrm{N}$ to urine and manure.

Using extreme examples, it is possible to demonstrate that dietary CP could be reduced for high-producing cows from 20 to $21 \%$ of diet DM to approximately $16 \%$ through diet modification, without impairing milk production. This would result in $22 \%$ less dietary $\mathrm{N}$ and approximately a $30 \%$ reduction in excreted N. Practically speaking, however, reducing dietary protein from about 17.5 to $18.5 \%$ to $16 \%$ through more precise ration balancing for high-producing cows is a more likely goal. This would result in a 10 to $15 \%$ reduction in dietary $\mathrm{N}$, and a 13 to $20 \%$ reduction in excreted $\mathrm{N}$.

Diet influences not only the amount of $\mathrm{N}$ excreted, but also the relative proportion of $\mathrm{N}$ in urine and feces. This can be important in that most of the urinary $\mathrm{N}$ will be in the form of urea, and urea can be quickly hydrolyzed by fecal microbes to ammonia when urine and feces mix following excretion. Ammonia is very vulnerable to being volatilized and lost to the atmosphere. Nitrogen in feces is more stable and less likely to be volatilized. The objective, therefore, would be to minimize urinary $\mathrm{N}$ relative to fecal $\mathrm{N}$. Feeding less dietary $\mathrm{N}$ will likely decrease both fecal and urinary $\mathrm{N}$, but will in most cases decrease urinary $\mathrm{N}$ the most.

Based on a compilation of 1801 nitrogen balance studies conducted at the USDA-ARS energy metabolism unit in Beltsville, MD, Wilkerson et al. (1997) noted the following distribution (\%) of $\mathrm{N}$ between feces, urine and milk: for cows producing an average of $29 \mathrm{~kg}$ milk/ d-34.8, 35.1, and $30.2 \%$, respectively; for cows producing an average of $14 \mathrm{~kg}$ milk/d-36.9, 39.9, and $23.2 \%$, respectively. For cows averaging $29 \mathrm{~kg}$ milk/d, average dietary CP was $16.6 \%$, and for cows averaging $14 \mathrm{~kg}$ milk/d, dietary CP averaged $15.5 \%$. Normally urinary $\mathrm{N}$ will account for 45 to $60 \%$ of total $\mathrm{N}$ excreted, and feces 40 to 55\% (Knowlton et al., 2001; Tine et al., 2001), but there can be significant deviation from these ranges (Krober et al., 2000).

Reducing $\mathrm{N}$ content of the diet is an efficient way to reduce gaseous $\mathrm{N}$ emissions from manure (Korevaar, 1992). Release of ammonia from manure in a flask was reduced by 32 and $40 \%$ when dietary CP content was reduced from 18.3 to $15.3 \%$ and from 16.4 to $12.3 \%$ in dairy cows (Paul et al., 1998). A relatively small reduction of an already low level of feed CP (11.0 vs 9.6\%) suppressed ammonia emission from fresh heifer manure by $28 \%$ (James et al., 1999). Smits et al. (1997) measured ammonia emissions in exhaust chimneys of 
a cattle barn and noted 39 and $24 \%$ lower emission when reducing feed CP from 19.8 to $14.6 \%$ and from 20.2 to $15.9 \%$, respectively.

Several strategies can be used to lower dietary protein, and one of these is to increase the amount of microbial protein synthesized in the rumen. Microbial protein is potentially the most economical protein we can hope to supply to the intestine. It is also a high-quality protein supplying lysine and methionine in proportion to their presence in milk (NRC, 2001). It is important to determine just how much potential there is for increasing the yield of microbial protein in the rumen. Highproducing cows, with their high DM intakes, have more rapid passage of digesta from the rumen than low-producing cows. That in itself promotes higher yields of microbial protein per unit DM fermented. Finely ground high-moisture shelled corn, through its ability to support microbial growth and protein synthesis, may be the cheapest "protein source" we have. The starch in some feed grains is more completely fermented in the rumen relative to the starch in corn, with barley starch being an example. Increasing fermentability of starch in feed grains will increase microbial protein production per unit of DM intake. Despite the fact that most of the corn produced is fed to livestock, and easily digestible corn starch is desired, corn breeders have selected grain that will resist shatter during handling through augers or various loading/unloading equipment. Such selection may have reduced starch digestibility. Small gains in rumen digestibility of grain starch are possible, and such change should translate into small increases in microbial protein production. This would have the potential of increasing the efficiency of dietary $\mathrm{N}$ use only if there was an excess supply of RDP. This is often the case with dairy diets, but probably not for feedlot beef diets. Improving digestibility of alfalfa through maceration (Broderick et al., 1999), and digestibility of corn silage, as in the example of brown midrib 3 corn (Oba and Allen, 1999), have the potential for increasing microbial protein yield per unit of DM intake. Increasing digestibility of forage cell walls through alterations in the chemical architecture of cell wall structure (Satter et al., 1999) has the potential of not only increasing available energy from forages, but also of increasing microbial protein synthesis.

A second strategy for reducing dietary protein is to fine tune and balance the supply of RUP and RDP. The new NRC (2001) requirement for total CP assumes that RUP and RDP will be provided in exactly the right amount. In practice, of course, it is difficult to achieve precise balance. The potential for use of high RUP supplements will depend to a significant extent upon the relative proportions of alfalfa silage and corn silage used in the dairy ration. If alfalfa silage makes up 30 to $40 \%$ or more of the forage, it is very likely that most or all of the supplemental protein should have a high RUP value. If $50 \%$ or more of the forage is corn silage, then it is likely that some or most of the supplemental protein could be supplied by a more degradable protein source, such as soybean meal. These are obviously broad generalizations, because other diet ingredients will also have an influence on what type of protein supplement is needed.

A third strategy is to balance diets more precisely for essential amino acids. As with poultry and swine, some potential exists for balancing dairy diets to provide the appropriate amounts of individual amino acids. Opportunities for improving efficiency of protein utilization through manipulation of dietary amino acid supply are not as great with ruminants as with swine and poultry. The reason is that the large amount of microbial protein produced in the rumen, representing 40 to $70 \%$ of protein reaching the intestine, is already well balanced regarding amino acids. Nonetheless, it is well documented that lysine and methionine are usually the most limiting amino acids for milk production, and that under the appropriate dietary situations small improvements can be made in $\mathrm{N}$ utilization by supplementing rumen protected lysine and/or methionine.

Since supplemented amino acids for ruminants have to be protected against degradation in the rumen, cost of amino acid supplementation for ruminants is higher than for poultry or swine. Supplementing two or more protected amino acids is generally cost prohibitive, but supplementing one protected amino acid oftentimes is feasible. It is less costly to provide the likely requirement of protected methionine than it is for protected lysine. An appropriate strategy is to formulate diets with feeds that are relatively rich in rumen undegraded lysine, and if necessary, supplement with protected methionine (Garthwaite et al., 1998). These workers have summarized a group of studies where either methionine, methionine plus lysine, or just lysine were used to supplement lactating cows. Overall, supplementing rumen-protected amino acids increased dry matter intake and milk production each by $0.5 \mathrm{~kg} / \mathrm{cow} \cdot$ day, milk protein by 0.15 percentage units $(68 \mathrm{~g})$, and milk fat by 0.06 percentage units $(45 \mathrm{~g})$. While these are indeed modest production increases, it is likely that some diet formulations will benefit from supplementation of rumen-protected methionine, especially when high-RUP soy supplements are fed. Further discussion of this topic is available (Garthwaite et al., 1998; Sloan et al., 1998).

There is no question that reducing dietary $\mathrm{N}$ content of dairy diets can significantly reduce total $\mathrm{N}$ excretion, as well as the proportion of excreted $\mathrm{N}$ that is in a form vulnerable to volatilization. Realistically, a 10 to $15 \%$ reduction in total dietary $\mathrm{N}$ in typical dairy diets is perhaps the maximum we can hope for with application of improved feeding programs. This translates into about a 13 to $20 \%$ reduction in manure $\mathrm{N}$, and perhaps 30 to $35 \%$ reduction in $\mathrm{N}$ that is vulnerable to volatilization. These are significant improvements, and when combined with appropriate crop rotations for feed production (where appropriate), and better manure handling, storage, and field application techniques, the combined practices can have a very important impact on $\mathrm{N}$ dynamics on dairy operations. 


\section{Feedlot Beef}

The majority ( 80 to $90 \%$ ) of the $\mathrm{N}$ fed to feedlot cattle is excreted. Dependent on diet, 50 to $75 \%$ of total excreted $\mathrm{N}$ is excreted as urinary urea $\mathrm{N}$ and 25 to $50 \%$ as fecal $\mathrm{N}$ by feedlot cattle (Giger-Reverdin et al., 1991). If typical, $85 \%$ grain-based diets are fed, then urinary $\mathrm{N}$ accounts for $75 \%$ or more of excreted $\mathrm{N}$. If hindgut fermentation is stimulated by readily fermentable carbohydrate sources reaching the large intestine, such as some corn by-product feeds, then route of excretion can shift to $50 \%$ fecal N and 50\% urinary N (Giger-Reverdin et al., 1991; Larson, 1992; Bierman et al., 1999).

Once $\mathrm{N}$ is excreted, various transformations occur both during storage and following manure application to cropping areas. Briefly, urea-N can be rapidly broken down by urease yielding bicarbonate and two $\mathrm{NH}_{4}+$ molecules. The following equation outlines urea hydrolysis:

$$
\mathrm{CO}\left(\mathrm{NH}_{2}\right)_{2}+\mathrm{H}^{+}+2 \mathrm{H}_{2} \mathrm{O} \rightarrow 2 \mathrm{NH}_{4}^{+}+\mathrm{HCO}_{3}{ }^{-}
$$

This conversion is rapid because urease enzyme is ubiquitous and produced by both microbes excreted in the feces and soil organisms on the pen surface (Mobley et al., 1995). Under optimal conditions, all the urea can be hydrolyzed within hours (Muck and Richards, 1980; Beline et al., 1998). The bicarbonate and ammonia act as buffers to maintain high $\mathrm{pH}$ which enhances $\mathrm{NH}_{4}{ }^{+}$ conversion to $\mathrm{NH}_{3}$ and subsequent volatilization (Varel et al., 1999).

Many of the processes that occur in the feedlot result in a large pool of $\mathrm{NH}_{4}{ }^{+}$from urine and feces N. $\mathrm{NH}_{4}{ }^{+}$ is not volatile and must be converted to $\mathrm{NH}_{3}$ before volatilization occurs. The conversion of $\mathrm{NH}_{4}{ }^{+}$to $\mathrm{NH}_{3}$ is controlled primarily by temperature, $\mathrm{pH}$, and concentration of $\mathrm{NH}_{4}{ }^{+}$(McCrory and Hobbs, 2001). Whether $\mathrm{NH}_{3}$ volatilizes is dependent on conversion of $\mathrm{NH}_{3}$ in solution to gaseous form. Whether $\mathrm{NH}_{3}$ is ultimately emitted from or deposited on the surface is dependent on ambient atmospheric concentrations relative to its concentration in soil at the pen surface (ApSimon et al., 1987; McCrory and Hobbs, 2001). In feedlot pens, the concentration of $\mathrm{NH}_{3}$ usually leads to emission into the atmosphere simply due to the concentration differences.

Two processes occur during manure decomposition that influence $\mathrm{NH}_{3}$ volatilization: biotic (microorganism-dependent) transformations or abiotic transformations (conversion of $\mathrm{NH}_{4}{ }^{+}$to $\mathrm{NH}_{3}$ independent of microorganisms; Dewes, 1996). Abiotic emissions are primarily controlled by concentration of $\mathrm{NH}_{4}^{+}$and concentration differences between $\mathrm{NH}_{3}$ in solution on the surface relative to surrounding atmospheric $\mathrm{NH}_{3}$ concentration.

As temperature increases, more $\mathrm{NH}_{4}{ }^{+}$is converted to $\mathrm{NH}_{3}$ resulting in greater volatilization losses (Dewes, 1996; Hargrove, 1988). The $\mathrm{pH}$ of both manure and soil receiving manure can have large impacts on $\mathrm{N}$ volatil- ization. Dewes (1996) evaluated $\mathrm{NH}_{3}$ volatilization at three $\mathrm{pH}$ values, 6.0, 7.5, and 9.0. Abiotic emission was nonsignificant at $\mathrm{pH} 6.0$ and 7.5, suggesting that very little $\mathrm{NH}_{4}{ }^{+}$was converted to $\mathrm{NH}_{3}$. At $\mathrm{pH} 6.0$, less than $1.0 \%$ of the $\mathrm{N}$ volatilized. At $\mathrm{pH} 9.0$, abiotic emissions accounted for up to $73 \%$ of the total $\mathrm{N}$ volatilized and equaled $10 \%$ of the initial $\mathrm{N}$. Total $\mathrm{N}$ lost at $\mathrm{pH} 9.0$ was only $14 \%$. Clearly, $\mathrm{pH}$ of manure, especially above 7.5 can have a tremendous impact on $\mathrm{N}$ volatilization. At high $\mathrm{pH}$, the increased volatilization appears to be directly correlated to the ratio of $\mathrm{NH}_{4}{ }^{+}: \mathrm{NH}_{3}$. The $\mathrm{pKa}$ of this equilibrium reaction is approximately 9 . Relative proportions of $\mathrm{NH}_{3}$ compared with $\mathrm{NH}_{4}^{+}$are approximately $0.1,1,10$ and $50 \%$ at $\mathrm{pH} 6,7,8$, and 9 , respectively. The economics and application of acid or baseprecipitating salts to lower $\mathrm{pH}$ of slurry or open-dirt feedlot manure are not a suitable control strategy at the current time (McCrory and Hobbs, 2001).

Nitrogen concentration in the diet can have a large impact on $\mathrm{NH}_{3}$ volatilization. As protein in the diet increases above the requirement, protein is still absorbed from the gut even though it is not needed. The excess protein $(\mathrm{N})$ needs to be dealt with by the animal and is usually excreted in the urine as urea. Because urea is rapidly hydrolyzed, then reducing urea excretion should result in reduced ammonia volatilization. Erickson et al. (2000b) decreased N intake by 11.4 and $18.4 \%$ for calves and yearling feedlot cattle, respectively (Table 2), by reducing dietary CP as animals progressed through the feeding period (phase feeding). The subsequent decrease in $\mathrm{N}$ excretion of 13 and $20 \%$ decreased $\mathrm{N}$ volatilization by 15 and $32 \%$ for calves fed in the winter and yearlings fed during the summer, respectively. Animal performance was similar between control and phase-fed groups despite lowering $\mathrm{N}$ intakes. Performance was maintained by utilizing the metabolizable protein (MP) system to meet and not exceed degradable intake protein (DIP) and MP requirements predicted by the beef NRC (1996). Using the MP system allowed for diets to be formulated more accurately and protein fractions provided in the diet to be changed as requirements change over time (i.e., phase-fed).

If two diets differ in protein content, then the higher protein diet will lead to increased urinary $\mathrm{N}$ excretion as urea (Merchen, 1993). The reason is that excess protein above the requirement must be metabolized to urea and excreted in urine. In these experiments, similar fecal $\mathrm{N}$ was probably excreted between treatments, but less urea $\mathrm{N}$ was excreted in urine by cattle on the Phase treatment due to lower protein intake. In general, urine is the predominant contributor to volatilization of $\mathrm{NH}_{3}$ when feces and urine are compared (Kellems et al., 1979). Because urea- $\mathrm{N}$ is rapidly converted to $\mathrm{NH}_{3}$ due to prevalence of urease enzyme (Mobley et al., 1995), then presumably more $\mathrm{N}$ would be volatilized if protein is overfed, such as with the Control group in Erickson et al. (2000b).

Based on current feeding trends in Nebraska and the U.S. (Nebraska Agricultural Statistics, 2000), approxi- 
Table 2. Nitrogen balance determined in the feedlot for both yearling experiments during the summer and calves during the winter spring months repeated across years (Erickson et al., 2000b). Diets contained 13.6\% (Control) or variable (12.8-10.5\%) protein depending on MP and DIP requirements Phase. All values are expressed as $\mathrm{kg} /$ steer over the entire feeding period

\begin{tabular}{|c|c|c|c|c|c|c|c|c|}
\hline \multirow[b]{2}{*}{ Item } & \multicolumn{4}{|c|}{ Yearlings (132 d) } & \multicolumn{4}{|c|}{ Calves (183 d) } \\
\hline & Control & Phase & $\mathrm{SE}$ & $P=$ & Control & Phase & $\mathrm{SE}$ & $P=$ \\
\hline Intake & 33.1 & 27.0 & 0.3 & 0.01 & 37.0 & 32.8 & 0.4 & 0.01 \\
\hline Retention $^{\mathrm{a}}$ & 3.6 & 3.6 & 0.02 & 0.80 & 4.6 & 4.6 & 0.03 & 0.28 \\
\hline Excretion $^{\mathrm{b}}$ & 29.5 & 23.4 & 0.3 & 0.01 & 32.4 & 28.2 & 0.4 & 0.01 \\
\hline Manure & 5.9 & 8.9 & 0.3 & 0.01 & 19.8 & 18.9 & 1.2 & 0.60 \\
\hline Soill $^{\mathrm{c}}$ & 1.7 & -0.4 & 0.6 & 0.03 & -1.7 & -2.9 & 0.8 & 0.28 \\
\hline Runoff & 1.0 & 0.7 & 0.1 & 0.07 & 1.0 & 1.0 & 0.1 & 0.74 \\
\hline Volatilized $^{\mathrm{d}}$ & 20.9 & 14.2 & 0.7 & 0.01 & 13.3 & 11.3 & 1.4 & 0.32 \\
\hline$\%$ Volatilized $^{\mathrm{e}}$ & 70.9 & 60.7 & & & 41.1 & 40.1 & & \\
\hline Manure+soil ${ }^{\mathrm{f}}$ & 7.6 & 8.5 & 0.7 & 0.39 & 18.1 & 15.9 & 1.3 & 0.24 \\
\hline
\end{tabular}

${ }^{a} \mathrm{~N}$ retention based on ADG and NRC (1996) equation for retained energy and retained protein.

${ }^{\mathrm{b}} \mathrm{N}$ excretion calculated as intake minus retention.

${ }^{\mathrm{c} S}$ Soil is core balance on pen surface before and after each experiment; negative values suggest removal of $\mathrm{N}$ present before initiation of experiment.

${ }^{\mathrm{d}}$ Volatilized calculated as excretion minus manure minus soil minus runoff.

e\% volatilized calculated as percentage of total excreted $\mathrm{N}$.

${ }^{\mathrm{f}}$ Manure+soil corrects what was hauled at cleaning by soil $\mathrm{N}$ remaining or removed from pen surface when compared with $\mathrm{N}$ on the pen surface before the experiment.

mately 64 to $70 \%$ of cattle are fed from November to May. Only 30 to $36 \%$ of cattle were in the feedlot from June to October from 1995 to 1998. If yearly volatilization rates are based on weighted averages for cattle on feed (65:35 ratio), then the amount of $\mathrm{N}$ that volatilizes is $53.5 \%$ of $\mathrm{N}$ excreted for the Control treatment. Similar calculations for Phase feeding results in $48.2 \%$ of $\mathrm{N}$ excreted being volatilized. The percentages are not greatly different, but total $\mathrm{kg}$ of $\mathrm{N}$ volatilized was reduced by $25 \%$ when Phase-fed cattle were compared with Control-fed cattle. Accounting for cattle inventory when calculating volatilization should be more accurate than basing $\mathrm{N}$ volatilization on summer and winter finishing systems separately. However, in these experiments, winter and summer finishing characteristics are confounded by type of animal (calf vs yearling) which have unique feeding characteristics. Despite estimates of 60 to $70 \%$ of $\mathrm{N}$ volatilizing in the summer experiments, the yearly volatilization rates using inventory of cattle and measurements here are similar to previous estimates (Gilbertson et al., 1971; Eghball and Power, 1994).

\section{Impact of Dietary Phosphorus on Phosphorus Output in Manure}

Phosphorus is a critical element with numerous and diverse functions in the body, including cell membrane structure (phospholipids), energy transfer (ATP), structure of DNA, and as an important constituent of bone. Approximately 80 to $83 \%$ of total body $\mathrm{P}$ is in bone and teeth, and in a $318 \mathrm{~kg}$ steer this will equal approximately 2,000 g (Wadsworth and Cohen, 1976). The nor- mal Ca:P ratio in bone is $2.1: 1$ and is relatively constant across species (Irving, 1963).

Maintaining adequate concentrations of $\mathrm{P}$ in soft tissue is critical to animal survival; thus maintenance of blood plasma concentrations of $\mathrm{P}$ within an acceptable range is of high priority for the animal. Plasma $\mathrm{P}$ concentrations are usually maintained between 4.0 to 8.0 $\mathrm{mg} / 100 \mathrm{~mL}$ (Underwood and Suttle, 1999). Short-term $\mathrm{P}$ deficiencies are accommodated by mobilizing $\mathrm{P}$ from bone, and this readily occurs without apparent impact on animal productivity. Once the mobile reserve of bone $\mathrm{P}$ is exhausted, then deficiency symptoms can appear, including a drop in plasma $\mathrm{P}$ concentration below $4 \mathrm{mg} /$ $100 \mathrm{~mL}$.

\section{Dairy Cattle}

There has been much confusion about the $\mathrm{P}$ requirement of lactating cows. This is reflected in large differences between feeding standards used by different countries in Europe and North America (Tamminga, 1992). Some of the standards differ by as much as threefold in their estimate of $\mathrm{P}$ maintenance requirements, and nearly twofold in the requirement for milk production. Likewise, large differences exist in estimates of $P$ availability in the gut. It is noteworthy, however, that the standards differ relatively little in their final recommendations for $\mathrm{P}$ feeding, as extreme differences in maintenance and lactation requirements tend to cancel each other. The NRC (2001) presents an excellent summary of $\mathrm{P}$ utilization by dairy cows, and does much to clarify what has been a murky area in the past.

The literature on $\mathrm{P}$ utilization and $\mathrm{P}$ requirements of lactating cows has been surprisingly consistent. It is 
in the interpretation of published reports where much confusion has arisen. This confusion has led to feeding of unrealistically large amounts of $\mathrm{P}$ in dairy diets. Several surveys (Bertrand et al., 1999; Sansinena et al., 1999; Satter, unpublished information) in the United States show that dairy diets are formulated to contain approximately 0.45 to $0.50 \% \mathrm{P}$ (DM basis), an amount that is about $20 \%$ in excess of the requirement (NRC, 2001). This oversupplementation of $P$ is costing the U.S. dairy industry about $\$ 100$ million annually, as well as increasing risk of environmental damage through eutrophication of lakes and streams.

How have we come to this point of excessive $\mathrm{P}$ feeding? There are at least three factors which have played a role. Perhaps most significant is the notion that increasing dietary $\mathrm{P}$ will improve reproductive performance. Studies in South Africa (Theiler and Green, 1932) demonstrated that supplementing bone meal to beef cows grazing dry season rangeland improved reproductive performance, as well as growth rates and survival rates. A widely cited field study in England (Hignett and Hignett, 1951) involving 802 dairy cows in 39 herds showed improved first-service conception rates when $\mathrm{P}$ was supplemented to those herds in the study having the lowest dietary $\mathrm{P}$ content. In both of these classic studies, dietary P levels were much lower than current NRC (2001) recommendations, and likely provided insufficient $\mathrm{P}$ for maximum rumen microbial growth. Durand and Kawashima (1980) suggested the maximum $\mathrm{P}$ requirement for ruminal microbes is $4 \mathrm{~g}$ $\mathrm{P} / \mathrm{kg}$ digestible organic matter in the diet. This would be equivalent to less than $0.30 \%$ dietary P. Extremely low dietary $\mathrm{P}$ can inhibit microbial growth, leading to reduced protein and energy supply to the host animal. It is well known that energy and protein supply can influence reproductive performance. Modern dairy diets never approach the low dietary $\mathrm{P}$ concentrations that can result in impaired microbial growth in the rumen. There is no evidence that feeding $\mathrm{P}$ in excess of NRC (2001) requirements will influence reproductive performance.

Another factor contributing to the overfeeding of $\mathrm{P}$ to dairy cows has been the absence of lactation trials showing the absolute minimum of $\mathrm{P}$ required to support moderate to high levels of milk production. Without knowing the bare minimum of $P$ needed to support milk production, arriving at a reasonable margin of safety in formulating diets becomes problematic. This uncertainty has led to overly large margins of safety and excessive $\mathrm{P}$ in the dairy diet. Information is now available to show that moderate- to high-producing dairy cows $(7,700$ to $13,000 \mathrm{~kg}$ milk/lactation) are likely to exhibit beginning signs of $\mathrm{P}$ deficiency following longterm feeding ( 1 to 3 lactations) of diets containing about 0.3\% P (Brintrup et al., 1993; Valk and Ebek, 1999; Wu et al., 2000; Wu et al., 2001).

A third factor contributing to overfeeding of $\mathrm{P}$ has been aggressive marketing of $\mathrm{P}$ supplements. This has probably been less important than the first two factors mentioned.

Figure 1 is a summary of the status of $P$ nutrition of lactating dairy cows producing $>9,000 \mathrm{~kg}$ milk/305 d lactation (Wu et al., 2001). The bare minimum of dietary $\mathrm{P}$ consistent with normal or near-normal animal performance is $0.30 \%$. At this dietary concentration, symptoms of $\mathrm{P}$ deficiency may begin to occur. At the other extreme of the continuum in Figure 1 is what most dairy producers in the United States are actually feeding. Figure 1 also shows the requirements for $\mathrm{P}$ as indicated by the NRC $(1989,2001)$. For ease of illustration, the NRC requirements are expressed in terms of percentage $\mathrm{P}$ in the diet. This is based on dry matter intakes suggested by the NRC. The most recent NRC (2001) publication has lowered slightly the requirement for $\mathrm{P}$ feeding, a change that is fully justified by research results. The NRC (2001) presents requirements, and does not include a margin of safety. In calculating the requirement, however, it appears the NRC (2001) committee used a somewhat conservative estimate for $\mathrm{P}$ availability, or the $\mathrm{P}$ absorption coefficient. The NRC (2001) model used P absorption (availability) coefficients of 64 and $70 \%$ for forages and concentrates, respectively. Recent unpublished research is suggesting that these values may be low. The long-term lactation studies mentioned earlier would confirm that the NRC (2001) requirements are more than sufficient, and one might in fact consider the NRC (2001) requirement to include a reasonable margin of safety.

It is difficult to determine what a reasonable margin of safety is with regard to $\mathrm{P}$ feeding. It will depend on uniformity of milk production of cows within the feeding group, variability of $\mathrm{P}$ content of diet ingredients, and how quickly cows exhibit P-deficiency symptoms. Variability in DM intake between animals of comparable milk production will also be a factor. The NRC (2001) suggests that Holstein cows weighing $680 \mathrm{~kg}$, having a body condition score of 3.0, that are $65 \mathrm{mo}$ of age, and producing milk containing $3.5 \%$ fat and $3.0 \%$ true protein will have a dietary requirement (using a sample diet) of $0.32,0.35,0.36$, and $0.38 \% \mathrm{P}$ for milk production amounts of $25.0,35.0,45.0$, and $54.4 \mathrm{~kg} / \mathrm{d}$, respectively. Certainly grouping cows by milk-production level would enable a closer match between dietary $\mathrm{P}$ and $\mathrm{P}$ requirement.

Based on information in NRC (2001) feed composition tables, it appears that the coefficient of variation for $\mathrm{P}$ content within a feedstuff listed is about $15 \%$. The NRC (2001) tabular values for P content of feedstuffs appear more accurate relative to the NRC (1988) tabular values, as the older NRC values for P content were systematically lower than recent laboratory analysis (Berger, 1995). This may be a reflection of increased soil $P$ levels in more recent years, since high soil $\mathrm{P}$ concentrations can result in elevated plant $\mathrm{P}$ content.

Cows lose both calcium and $\mathrm{P}$ from bone to help supply these elements in early lactation. Ternouth (1990) suggested that up to $30 \%$ of bone $\mathrm{P}$ can be removed 
NRC Recommendations (1989 and 2001)

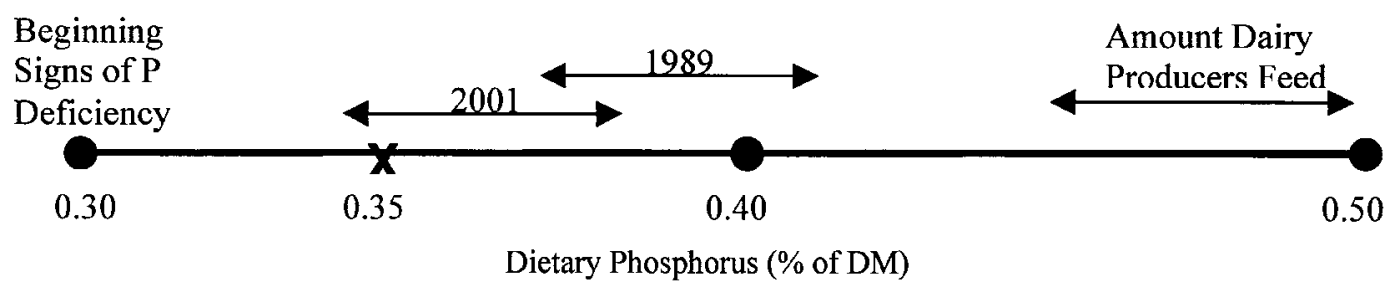

Figure 1. Current status of $\mathrm{P}$ nutrition of lactating dairy cows milking $>9,000 \mathrm{~kg} / 305 \mathrm{~d}$ of lactation.

during early lactation. Based on this estimate for beef cows, a dairy cow weighing $600 \mathrm{~kg}$ could mobilize 600 to $1000 \mathrm{~g}$ of $\mathrm{P}$ in early lactation. Phosphorus mobilized from bone would need to be restored in later lactation, but the sizeable bone reserve provides a buffer against short-term $\mathrm{P}$ deficiencies that might result from underestimating $\mathrm{P}$ content of a batch of feed. Also, mobilized bone $\mathrm{P}$ reduces the need for elevated dietary $\mathrm{P}$ levels in the first weeks of lactation when feed intake lags behind milk production.

With this background, a reasonable approach might be to formulate group rations using NRC (2001) recommendations to match the average production level of the top $25 \%$ of cows in a feeding group. If this is done, then high production groups in the highest producing herds would have their $\mathrm{P}$ requirement met, with a reasonable margin of safety, with diets containing 0.36 to $0.40 \% \mathrm{P}$. This amount of dietary $\mathrm{P}$ can be supplied with little or no use of $\mathrm{P}$ supplements, and it represents a $20 \%$ reduction in $\mathrm{P}$ content of the average dairy diet in the United States.

Phosphorus fed in excess of the requirement is excreted, with the vast majority appearing in the feces. Typically cows fed just enough $\mathrm{P}$ to meet their requirement will excrete $<1 \mathrm{~g}$ P/d in urine. Cows fed P 20 to $30 \%$ in excess of their requirement may excrete 3 to 5 $\mathrm{g} \mathrm{P} / \mathrm{d}$ in urine (Wu et al., 2000). Table 3 contains results from a lactation study where cows were fed diets containing $0.31,0.39$, or $0.47 \% \mathrm{P}$ for a 308 -d lactation (Wu et al., 2001). Based on bone $\mathrm{P}$ and ash content, cows fed the $0.31 \% \mathrm{P}$ diet were marginally deficient. Phos- phorus fed in excess of the requirement, which in this example was close to $0.31 \%$, was excreted. Referring to Figure 1, reducing $\mathrm{P}$ content of average U.S. dairy diets from 0.45 to 0.50 to 0.36 to $0.40 \%$ represents a $20 \%$ reduction in dietary $\mathrm{P}$, and at least a $25 \%$ reduction in manure $\mathrm{P}$.

Reducing dietary $\mathrm{P}$ concentration not only reduces $\mathrm{P}$ content of manure, but it reduces the vulnerability of $\mathrm{P}$ in manure from being solubilized in runoff water following field application. Ebeling et al. (2002) obtained manure from lactating cows fed dietary $P$ concentrations of 0.32 or $0.48 \%$. These dietary levels resulted in feces with $\mathrm{P}$ concentrations of 0.48 and $1.28 \%$, respectively. This manure was surface applied to field plots without incorporation. Phosphorus load in water runoff from the plots was about ten times greater in plots amended with manure derived from cows fed the high$\mathrm{P}$ diet than manure from cows fed the low-P diet. When these manures were applied at equivalent rates of $\mathrm{P}$ (40 kg/ha), the high-P manure had $\mathrm{P}$ runoff loads about four times that of the low-P manure. A related study was reported by Dou et al. (2001). They measured water solubility of $\mathrm{P}$ in manure obtained from cows fed different amounts of dietary P. Their study indicated that most of the $\mathrm{P}$ fed in excess of the requirement ended up as water-soluble $\mathrm{P}$ in the manure. Therefore, reducing dietary $\mathrm{P}$ not only reduces $\mathrm{P}$ content of manure, but also greatly reduces the amount of soluble $\mathrm{P}$ in manure and the potential for field runoff of what manure $\mathrm{P}$ is applied.

Reducing dietary P can have a very significant effect on the amount of land required to effectively utilize

Table 3. Performance of cows fed diets differing in phosphorus content for an entire lactation ( $\mathrm{Wu}$ et al., 2001)

\begin{tabular}{lccc}
\hline \hline & \multicolumn{3}{c}{ Dietary P (\% of DM) } \\
\cline { 2 - 4 } Item & 0.31 & 0.39 & 0.47 \\
\hline Number of cows & 10 & 14 & 13 \\
Dry matter intake, kg/d & 25.0 & 25.0 & 24.6 \\
Milk, kg/308 d & 13,038 & 11,909 & 12,126 \\
Milk fat, \% & 3.64 & 3.50 & 3.64 \\
Milk protein, \% & 3.16 & 3.13 & 3.10 \\
P intake, g/d & 77.5 & 97.5 & 115.6 \\
Fecal P excretion, g/d & 43 & 66 & 88 \\
\hline
\end{tabular}

${ }^{a}$ Estimated using $68 \%$ as the diet DM digestibility, and the means for DMI and fecal $\mathrm{P}$ concentrations $(0.538,0.829$, and $1.12 \%$ for the three treatments, respectively). 
Table 4. Amount of phosphorus fed and excreted by a lactating cow producing $9,090 \mathrm{~kg}$ milk in 305 day, and the amount of land required to effectively utilize the manure phosphorus ${ }^{\mathrm{a}}$

\begin{tabular}{lcccc}
\hline \hline $\begin{array}{l}\text { Dietary P } \\
\text { concentration } \\
(\%)\end{array}$ & $\begin{array}{c}\text { Estimated } \\
\text { Supplemental P } \\
\text { (kg/lactation) }\end{array}$ & $\begin{array}{c}\text { Manure P } \\
\text { (kg/lactation) }\end{array}$ & $\begin{array}{c}\text { Land area needed } \\
\text { to recycle manure P } \\
(\text { ha) }\end{array}$ & $\begin{array}{c}\text { Change in } \\
\text { land area } \\
(\%)\end{array}$ \\
\hline 0.35 & 0 & 15.8 & 0.53 & Base \\
0.40 & 3.4 & 19.2 & 0.65 & 23 \\
0.48 & 8.9 & 24.7 & 0.81 & 53 \\
0.55 & 13.7 & 29.5 & 0.97 & 83 \\
\hline
\end{tabular}

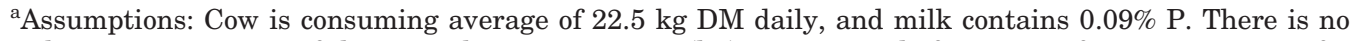
net change in $\mathrm{P}$ content of the cow. The cropping area (ha) is comprised of $37 \%$ corn for grain, $7 \%$ corn for silage, $47 \%$ alfalfa, and $9 \%$ soybeans. Crop yields are typical for the midwest US, and remove $29.9 \mathrm{~kg} \mathrm{P}$ per ha per year.

manure P (Table 4). Most lactation diets that are not supplemented with an inorganic $\mathrm{P}$ source contain 0.35 to $0.40 \% \mathrm{P}$. This of course depends on the ration ingredients used. Since this concentration is similar to the $\mathrm{P}$ requirement for lactating cows, it follows that essentially all of the supplemental $\mathrm{P}$ fed above the requirement will be excreted in the manure. Assuming a crop uptake of $29.9 \mathrm{~kg} \mathrm{P} / \mathrm{ha} \cdot \mathrm{yr}$, the requirement for land increases proportionally with the increase in manure $\mathrm{P}$. Reducing dietary $\mathrm{P}$ to an amount that the lactating cow requires often means complete elimination of mineral $\mathrm{P}$ supplements. It can also result in a major reduction in the amount of land required to effectively utilize manure $\mathrm{P}$.

The dairy industry utilizes large amounts of by-product feeds, many of which serve as important sources of protein in the dairy diet. There is a tendency for feedstuffs that are high in protein content to also contain high concentrations of $\mathrm{P}$, but there are significant deviations from this generalization. Table 5 shows the N:P ratio of some common dairy supplements that are often brought into the ration because of their protein content. Bloodmeal and meat and bone meal represent the extremes in this table. Both feedstuffs are high in RUP content, but bloodmeal supplies a very large amount of protein per unit of $\mathrm{P}$. Meat and bone meal, on the other hand, supplies relatively little protein per unit of $\mathrm{P}$. The NRC (2001) values presented in Table 5 for meat and bone meal are not identified by the NRC publication as being of porcine or ruminant origin. It appears that on average porcine meat and bone meal contains slightly more protein and less $\mathrm{P}$ than ruminant meat and bone meal, and that the $\mathrm{N}: \mathrm{P}$ ratio of porcine meal may typically range between 2 and 3 . This might be worth noting since only porcine meat and bone meal can be fed to ruminants.

For dairy producers that are having trouble managing $\mathrm{P}$, choice of a protein supplement or by-product feed can be an important decision affecting $\mathrm{P}$ management. A growing number of dairy producers have discontinued using $\mathrm{P}$ supplements, but because they utilize large amounts of by-product feeds high in $\mathrm{P}$ concentration, overall dietary $\mathrm{P}$ content may still be excessive ( 0.40 to $0.45 \%)$. It is important that least-cost ration formulation programs do not give credit for $\mathrm{P}$ content of a feedstuff if the diet does not need P. A significant part of the dollar value of meat and bone meal is associated with its $\mathrm{P}$ content. If $\mathrm{P}$ is not needed, then meat and

Table 5. Protein and phosphorus content of some common feeds (NRC, 2001)

\begin{tabular}{lcccr}
\hline \hline & $\begin{array}{c}\text { Protein } \\
\text { content } \\
\text { \% of DM }\end{array}$ & $\begin{array}{c}\text { N content } \\
\text { \% of DM }\end{array}$ & $\begin{array}{c}\text { Phosphorus } \\
\text { content } \\
\text { \% of DM }\end{array}$ & N:P \\
\hline Bloodmeal & 95.5 & 15.3 & 0.30 & 51.0 \\
Soybean meal (48\% CP) & 49.9 & 8.0 & 0.70 & 11.4 \\
Soybean (roasted) & 43.0 & 6.9 & 0.64 & 10.8 \\
Brewer's grains & 29.2 & 4.7 & 0.67 & 7.0 \\
Cottonseed & 23.5 & 3.8 & 0.60 & 6.3 \\
Corn distillers grains & 29.7 & 4.8 & 0.83 & 5.8 \\
Canola meal & 37.8 & 6.0 & 1.10 & 3.8 \\
Corn gluten feed & 23.8 & 3.8 & 1.00 & 2.9 \\
Wheat midds & 18.5 & 3.0 & 1.02 & 2.4 \\
Wheat bran $_{\text {Meat and bone meal }}{ }^{\mathrm{a}}$ & 17.3 & 2.8 & 1.18 & 1.8 \\
\hline
\end{tabular}

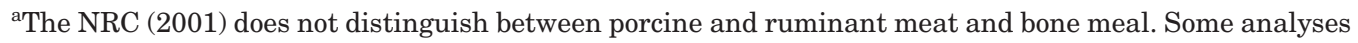
suggest that porcine meat and bone meal tends to have more protein and less $\mathrm{P}$ than ruminant meat and bone meal, resulting in a N:P ratio between 2 and 3 . 
bone meal should not be given credit for the $\mathrm{P}$ it contributes in excess of the requirement. In fact, a negative value might be appropriately assigned in some cases.

Ruminal microorganisms are a source of phytase for ruminants, and unlike poultry and swine, ruminants are able to utilize nearly all of the phytate $\mathrm{P}$ present in grains (NRC, 2001). It is possible, however, that small amounts of phytate $\mathrm{P}$ can escape the rumen and not be available for absorption in the intestine. Corn mutants that have 33 to $66 \%$ less phytate $\mathrm{P}$, but the same amount of total P (Raboy and Gerbasi, 1996), may slightly increase $\mathrm{P}$ availability in ruminants. At best, use of low-phytate corn in dairy diets would only marginally reduce the dietary $\mathrm{P}$ requirement.

Reducing dietary $\mathrm{P}$ in lactating cow diets is perhaps one of the most effective steps that can be taken to reduce the environmental threat of dairy manure. It is a step that reduces cost as well as provides environmental benefits. The $\mathrm{P}$ content of most dairy diets can be reduced by about $20 \%$, thus lowering manure P by 25 to $30 \%$.

\section{Feedlot Beef}

Requirements. A factorial approach, dividing the $\mathrm{P}$ requirement between maintenance and growth, is typically used. The NRC (1996) requirement for maintenance is $16 \mathrm{mg} / \mathrm{kg}$ of body weight in beef cattle. Therefore, for typical feedlot cattle weighing 300 to $600 \mathrm{~kg}$, the maintenance requirement is predicted as 4.8 to 9.6 $\mathrm{g} / \mathrm{d}$. This amount of $\mathrm{P}$ must be absorbed, which is different than the amount required in the diet. To accurately determine dietary requirement, availability and digestibility must be considered. The NRC (1996) assumes that $68 \%$ of dietary $\mathrm{P}$ will be absorbed. Therefore, the dietary $\mathrm{P}$ requirement for maintenance is 7.1 to $14.1 \mathrm{~g} /$ $\mathrm{d}$ for feedlot cattle weighing 300 to $600 \mathrm{~kg}$.

The requirement for growth is calculated as $3.9 \mathrm{~g}$ for every $100 \mathrm{~g}$ of retained protein (NRC, 1996). Calculated retained protein for feedlot cattle gaining between 1.5 to $2.2 \mathrm{~kg} / \mathrm{d}$ is approximately 150 to $220 \mathrm{~g} / \mathrm{d}$. As gain increases, amount of $\mathrm{P}$ required increases. The requirement for gain is based on an experiment conducted by Ellenberger et al. (1950), where 129 entire carcasses (dairy breed) from the fetus through $12 \mathrm{yr}$ of age were analyzed for P. Phosphorus retention was then estimated from whole-body analyses to correlate $\mathrm{P}$ with protein retained. The study was quite extensive and represents the only experiment conducted to obtain accurate estimates of $\mathrm{P}$ retention. Inherent in the requirement for gain is the assumption that $\mathrm{P}$ retention is equal to the requirement for gain.

Durand and Komisarczuk (1988) concluded that under normal situations when dietary phosphorus and calcium are sufficient to meet the animal's requirement, plasma phosphorus concentration is adequate to maintain saliva concentrations, and the microbial phosphorous requirement is met. During severe deficiency, low plasma concentration will limit phosphorus supplied by saliva (Challa et al., 1989). A severe phosphorus deficiency will also decrease feed intake causing saliva flow to decrease as well. This scenario will limit microbial growth, decrease digestibility, and volatile fatty acid production.

Feeding Trials. Tillman et al. (1959) conducted an experiment with calves 6 mo old and weighing $160 \mathrm{~kg}$ and gaining approximately $0.5 \mathrm{~kg} / \mathrm{d}$. Gain increased linearly when P was increased from $5.3(0.14 \%)$ to 8.9 $(0.20 \%) \mathrm{g} / \mathrm{d}$. Wise et al. (1958) conducted two experiments with $90-\mathrm{kg}$ Holstein male calves approximately 3 mo of age. Concentrations of dietary $\mathrm{P}$ evaluated were $0.09,0.12,0.18$, and $0.30 \%$ (experiment I) and 0.14 , $0.22,0.30$, and $0.38 \%$ (experiment II). In experiment I, calf gains were improved linearly up to $0.18 \%$ from 0.38 to $0.62 \mathrm{~kg} / \mathrm{d}$, and then increased to $0.69 \mathrm{~kg} / \mathrm{d}$ with the $0.30 \%$ dietary P. Efficiencies and femur growth followed similar trends. In experiment II, weight gain, efficiency, and bone growth were improved with animals supplemented with $0.22 \% \mathrm{P}$; however, there was no further improvement in performance or bone status with the higher levels of dietary P. Long et al. (1957) conducted two experiments with $180-\mathrm{kg}$ calves to evaluate three levels of $\mathrm{P}$ for growth $(0.09,0.14$, and $0.18 \%$ of $\operatorname{diet} \mathrm{DM})$. Gains ( 0.09 to $0.61 \mathrm{~kg} / \mathrm{d})$ and efficiencies were improved by supplementation of phosphorus.

When cattle get both older and larger, presumably the $\mathrm{P}$ requirement decreases. A limited number of $\mathrm{P}$ requirement studies have been conducted with yearlings or larger animals. Burroughs et al. (1956) evaluated diets containing $0.18,0.25,0.33 \% \mathrm{P}$ fed to yearling steers receiving a $60 \%$ concentrate diet until market. Gains and efficiencies were improved up to $0.25 \% \mathrm{P}$. No further improvement was noted when $\mathrm{P}$ was increased to $0.33 \%$. Similarly, Long et al. (1956) evaluated the $\mathrm{P}$ required for developing yearling heifers. The authors found linear increases in intake, weight gain, and plasma $\mathrm{P}$ over the range of $0.07,0.11$, and $0.15 \%$ dietary $P$.

Call et al. (1978) conducted a two-year experiment with maturing heifers. One group was fed a diet that contained $66 \%$ of NRC-predicted requirement for P $(0.16 \%)$, whereas the other group was supplemented with monosodium phosphate to increase dietary $\mathrm{P}$ to $0.41 \%$. Feed intake, weight gain, pregnancy rate, and live calf percentage were not different between the two treatments. These data suggest that $\mathrm{P}$ supplementation for cows may be an unnecessary cost if dietary phosphorus exceeds $0.16 \%$ of DM. Phosphorus retention was also similar between treatments and the authors concluded that urine and fecal excretion of $\mathrm{P}$ was significantly greater for $\mathrm{P}$-supplemented heifers. Average phosphorus intakes were 9.0 and $11.6 \mathrm{~g} /$ $\mathrm{d}$ for yr 1 and 2 with the $0.16 \% \mathrm{P}$ treatment. The supplemented group received 21.6 and $30.6 \mathrm{~g} / \mathrm{d}$ for $\mathrm{yr}$ 1 and 2. This experiment was continued for $10 \mathrm{yr}$ with $\mathrm{P}$ intakes varied over time to determine the amount required by the beef cow (Call et al., 1986). The authors concluded that the amount of phosphorus re- 


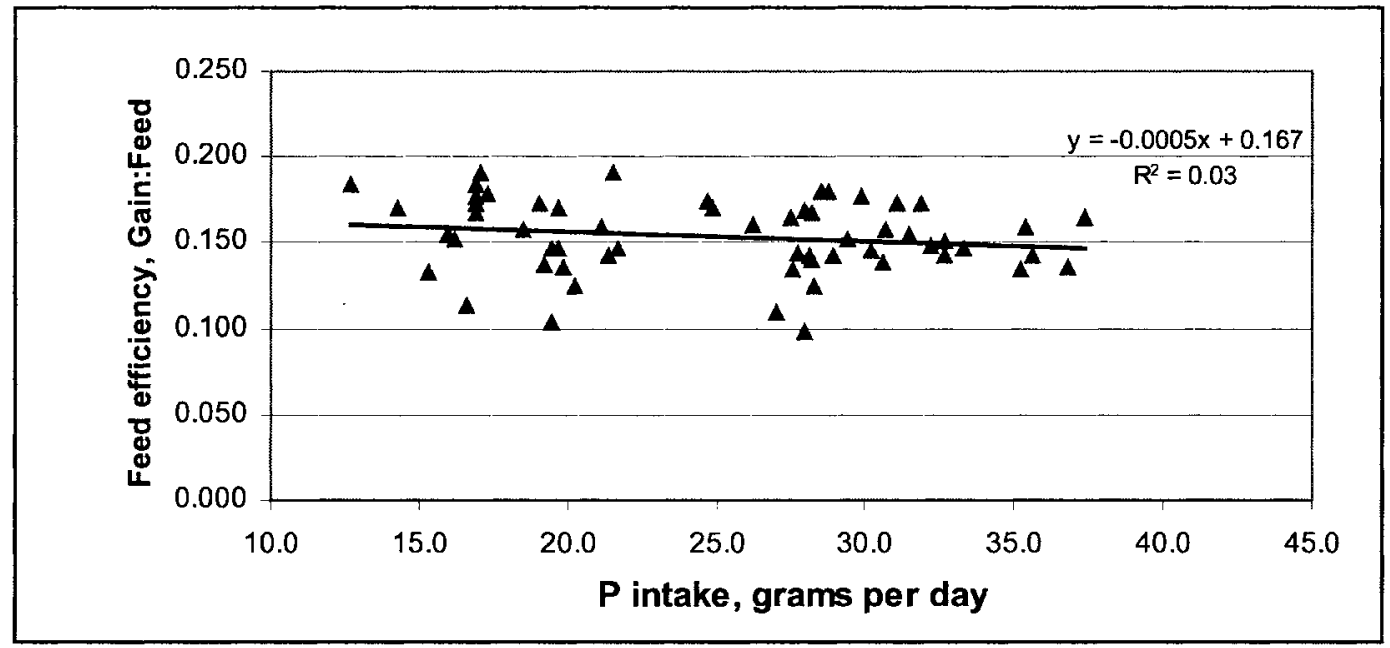

Figure 2. Feed efficiency scatterplot showing relationship to $\mathrm{P}$ intake for yearling steers fed $0.14,0.19,0.24,0.29$, or 0.34\% P for $105 \mathrm{~d}$ (Erickson et al., 1999). Phosphorus intake expressed in g/d based on DMI, \% P of diet DM, and P refused. Each dot represents individual steer performance.

quired was between 7.8 and $8.9 \mathrm{~g} / \mathrm{d}$. Cows fed 5.1 to 6.6 $\mathrm{g} / \mathrm{d}$ of phosphorus gradually developed clinical signs of deficiency within 6 mo.

Because of a lack of data for feedlot cattle commonly fed today, Erickson et al. (1999) conducted a P requirement study with individually fed yearling steers. Treatments consisted of $0.14,0.19,0.24,0.29$, or $0.34 \%$ dietary P (DM basis). Phosphorus intakes ranged from 14 to $36 \mathrm{~g} / \mathrm{d}$, or 71 to $160 \%$ of current NRC predicted requirements. Based on animal performance and bone characteristics, no treatment effects were detected over the 105-d experiment with these larger $(380 \mathrm{~kg})$ yearling steers. Feed efficiency was not related to $\mathrm{P}$ intake (Figure 2). However, the steers used in this experiment were larger. Smaller, younger calves that may be placed in feedlots today could conceivably require $\mathrm{P}$ supplementation. Therefore, a similar experiment was conducted with steer calves weighing $265 \mathrm{~kg}$. Calves were fed $0.16,0.22,0.28,0.34$, or $0.40 \%$ P. Phosphorus intake ranged from 14 to $36 \mathrm{~g} / \mathrm{d}$, or 76 to $190 \%$ of NRC recommendations for these animals. Performance and bone mineral content were unaffected by $\mathrm{P}$ intake (Erickson et al., 2002). However, plasma inorganic $\mathrm{P}$ did respond quadratically with the lowest concentrations observed in steers fed $0.16 \%$ P. Feed efficiency was not related to $\mathrm{P}$ intake (Figure 3).

These data suggest that animals consuming high grain finishing diets do not require supplementation of

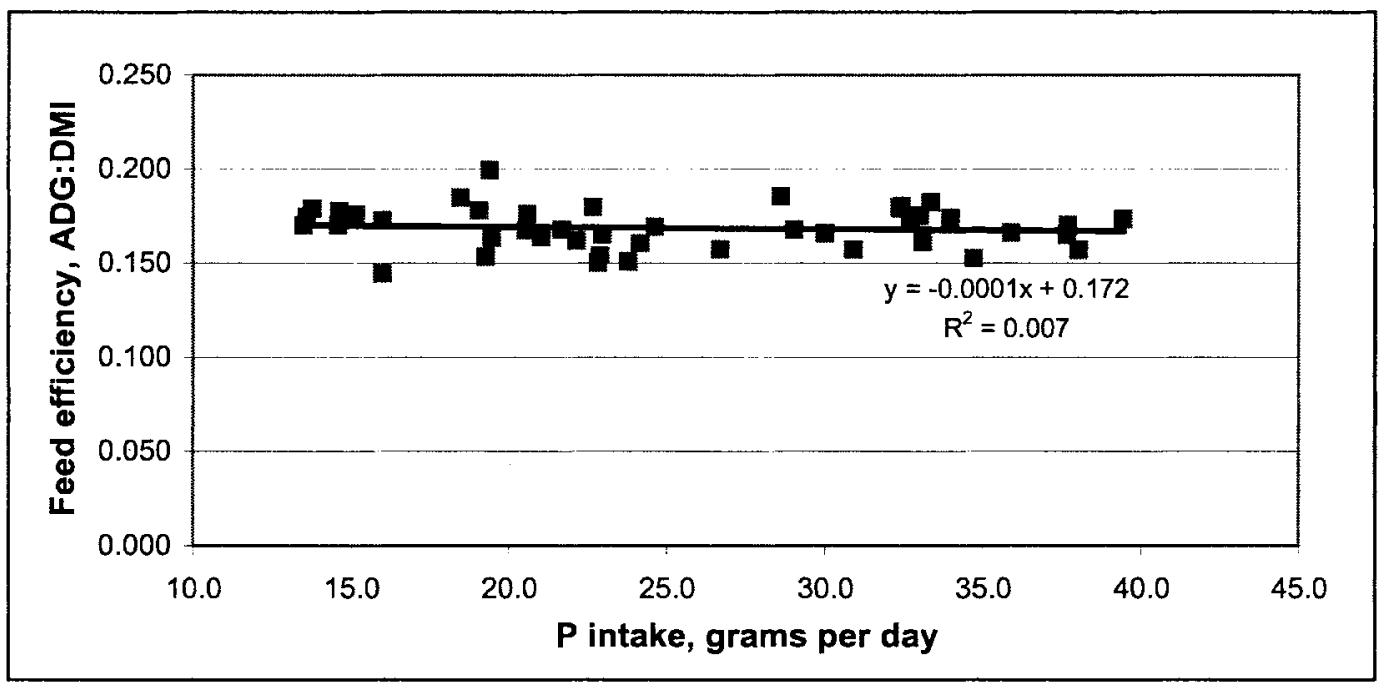

Figure 3. Feed efficiency scatterplot showing relationship to $\mathrm{P}$ intake for steer calves fed $0.16,0.22,0.28,0.34$, or $0.40 \% \mathrm{P}$ for $204 \mathrm{~d}$ (Erickson et al., 2002). Phosphorus intake expressed in $\mathrm{g} / \mathrm{d}$ based on DMI, \% P of diet DM, and P refused. Each dot represents individual steer performance. 
Table 6. Phosphorus (P) balance in the feedlot for the yearling and calf experiments combined across both years (values expressed as $\mathrm{kg} / \mathrm{steer}$; $132 \mathrm{~d}$ for yearlings and $183 \mathrm{~d}$ for calves; Erickson et al., 2000a)

\begin{tabular}{|c|c|c|c|c|c|c|c|c|}
\hline \multirow[b]{2}{*}{ Item } & \multicolumn{4}{|c|}{ Yearlings } & \multicolumn{4}{|c|}{ Calves } \\
\hline & $\begin{array}{c}\text { Control } \\
0.37 \%\end{array}$ & $\begin{array}{l}\text { Low P } \\
0.25 \%\end{array}$ & $\mathrm{SE}$ & $P=$ & $\begin{array}{c}\text { Control } \\
0.37 \%\end{array}$ & $\begin{array}{l}\text { Low P } \\
0.25 \%\end{array}$ & $\mathrm{SE}$ & $P=$ \\
\hline Intake & 5.83 & 3.28 & 0.05 & 0.01 & 6.81 & 4.50 & 0.07 & 0.01 \\
\hline Retention $^{\mathrm{a}}$ & 0.87 & 0.88 & 0.01 & 0.82 & 1.12 & 1.11 & 0.01 & 0.24 \\
\hline Excretion $^{\mathrm{b}}$ & 4.95 & 2.40 & 0.05 & 0.01 & 5.69 & 3.39 & 0.07 & 0.01 \\
\hline
\end{tabular}

${ }^{\mathrm{a} P}$ retention based on ADG and NRC (1996) equation for retained energy, retained protein and P.

${ }^{\mathrm{b}} \mathrm{P}$ excretion calculated as intake minus retention.

phosphorus. Assuming low feed intakes (8 kg DM/d) and no $\mathrm{P}$ supplementation (minimum of $0.2 \%$ phosphorus from grain alone), then the animal would consume $16 \mathrm{~g} / \mathrm{d}$ of $\mathrm{P}$. Therefore, P supplementation is an unnecessary monetary and environmental cost to the producer. The data that are available suggest the NRC recommendations for $\mathrm{P}$ are too high. Despite the conclusion that NRC recommendations are too high, the industry commonly supplements feedlot diets with inorganic $\mathrm{P}$ and criticizes the NRC predictions as being too low. Consequently, diets are commonly formulated with a large safety margin (Spears, 1996).

Table 6 illustrates the impact dietary $\mathrm{P}$ concentration has on $\mathrm{P}$ excretion by steer calves and yearlings (Erickson et al., 2000a). A diet formulated to meet and not exceed NRC recommendations (Low P) was compared with diets containing conventional concentrations of $\mathrm{P}$ (Control). Based on $\mathrm{P}$ analysis, diets contained 0.25 and $0.37 \% \mathrm{P}$ for Low $\mathrm{P}$ and Control, respectively. Compared with the Control groups, feeding Low $\mathrm{P}$ decreased $(P<$ $0.01) \mathrm{P}$ intake without affecting $(P>0.24) \mathrm{P}$ retained by the animal. Based on NRC equations, retention is directly related to $\mathrm{ADG}$. In these experiments, $\mathrm{ADG}$ was not affected by dietary $P$. Calves did retain more $\mathrm{P}$ than yearlings, probably due to greater bone growth during the feeding period. Compared with the Control group, feeding Low P decreased P excretion by 55\% (2.55 kg/steer or $19.3 \mathrm{~g} / \mathrm{d}$ during the 132 -d experiment) for the yearling steers, and $40 \%(2.30 \mathrm{~kg} / \mathrm{steer}$ or 12.4 $\mathrm{g} / \mathrm{d}$ during the 183-d experiment for the steer calves.

The $P$ requirement for growing beef animals is easily met by the usual feed ingredients in the feedlot diet. In many instances it would be cost prohibitive to lower $\mathrm{P}$ content of feedlot diets beyond the obvious step of removing all supplemental $P$. It is very clear, however, that inorganic $P$ supplements are not necessary in feedlot diets, and they contribute only added cost and environmental risk.

\section{Implications}

The potential for reducing dietary $\mathrm{N}$ through more precise formulation of diets for rumen undegraded protein and rumen degraded protein, and phase feeding or grouping of animals more closely according to produc- tion level, will enable reduction of 10 to $15 \%$ of dietary $\mathrm{N}$. This results in about 13 to $20 \%$ reduction in N excretion, and potential reduction of 25 to $35 \%$ in the amount of $\mathrm{N}$ lost as $\mathrm{NH}_{3}$ to the atmosphere. Dietary P levels can be reduced somewhat more, with reductions of $20 \%$ or more quite possible. All mineral $\mathrm{P}$ supplements should be removed from beef feedlot diets, and most if not all supplemental $\mathrm{P}$ removed from lactating dairy cow diets. The requirement for $\mathrm{P}$ by feedlot beef animals is likely to be somewhat below the $\mathrm{P}$ supplied by grain in feedlot diets. Reducing $\mathrm{P}$ content of dairy diets by $20 \%$ will reduce excretion of $\mathrm{P}$ in manure by more than $25 \%$. In addition, the $\mathrm{P}$ that is excreted in manure when reduced $\mathrm{P}$ diets are fed is less susceptible to field runoff.

\section{Literature Cited}

ApSimon, H., M. M. Kruse, and J. N. B. Bell. 1987. Ammonia emissions and their role in acid deposition. Atmos. Environ. 21:1939-1946.

Beline, F., J. Martinez, C. Marol, and G. Guirand. 1998. Nitrogen transformation during anaerobically stored 15N-labelled pig slurry. Bioresour. Technol. 64:83-88.

Berger, L. L. 1995. Why do we need a new NRC data base? Anim. Feed Sci. Technol. 53:99-107.

Bertrand, J. A., J. C. Fleck, and J. C. McConnell, Jr. 1999. Phosphorus intake and excretion on South Carolina Dairy Farms. Prof. Anim. Sci. 15:264-267.

Bierman, S., G. E. Erickson, T. J. Klopfenstein, R. A. Stock, and D. H. Shain. 1999. Evaluation of nitrogen and organic matter balance in the feedlot as affected by level and source of dietary fiber. J. Anim. Sci. 77:1645-1653.

Brintrup, R., T. Mooren, U. Meyer, H. Spiekers, and E. Pfeffer. 1993. Effects of two levels of phosphorus intake on performance and fecal phosphorus excretion of dairy cows. J. Anim. Physiol. Anim. Nutr. 69:29-36.

Broderick, G. A., R. G. Koegel, M. J. C. Mauries, E. Schneebergen, and T. J. Kraus. 1999. Effect of feeding macerated alfalfa silage on nutrient digestibility and milk yield in lactating dairy cows. J. Dairy Sci. 82:2472-2485.

Burroughs, W., A. Raun, E. Cheng, and C. C. Culbertson. 1956. Different kinds and amounts of phosphorus in fattening cattle rations. Iowa State College A.H. Leaflet 209:1-5.

Call, J. E., J. W. Butcher, J. T. Blake, R. A. Smart, and J. L. Shupe. 1978. Phosphorus influence on growth and reproduction of beef cattle. J. Anim. Sci. 47:216-225.

Call, J. W., J. E. Butcher, J. L. Shupe, J. T. Blake, and A. E. Olson. 1986. Dietary phosphorus for beef cows. Am. J. Vet. Res. 47:475-481.

Challa, J., G. D. Braithwaite, and M. S. Dhanoa. 1989. Phosphorus homeostasis in growing calves. J. Agric. Sci. 112:217-226. 
Christensen, R. A., G. L. Lynch, and J. H. Clark. 1993. Influence of amount and degradability of protein on production of milk and milk components by lactating Holstein cows. J. Dairy Sci. 76:3490-3496.

Cunningham, K. D., M. J. Cecava, T. R. Johnson, and P. A. Ludden. 1996. Influence of source and amount of dietary protein on milk yield by cows in early lactation. J. Dairy Sci. 79:620-630.

Dewes, T. 1996. Effect of $\mathrm{pH}$, temperature, amount of litter and storage density on ammonia emissions from stable manure. J. Agric. Sci. 127:501-509.

Dhiman, T. R., C. Cadorniga, and L. D. Satter. 1993. Protein and energy supplementation of high alfalfa silage diets during early lactation. J. Dairy Sci. 76:1945-1959.

Dhiman, T. R., and L. D. Satter. 1993. Protein as the first-limiting nutrient for lactating dairy cows fed high proportions of good quality alfalfa silage. J. Dairy Sci. 76:1960-1971.

Dou, Z., K. Knowlton, G. Zhang, Z. Wu, and R. Kohn. 2001. Lowering dietary $\mathrm{P}$ in dairy rations reduces the vulnerable $\mathrm{P}$ fraction in manure. J. Dairy Sci. 84 (Suppl.1):254 (Abstr.)

Durand, M., and R. Kawashima. 1980. Influence of minerals in rumen microbial digestion. Pages 375-408 in Digestive Physiology and Metabolism in Ruminants. Y. Ruckebusch and P. Thivend, ed. MTP Press Ltd., Lancaster, England.

Durand, M., and S. Komisarczuk. 1988. Influence of major minerals on rumen microbiota. J. Nutr. 118:249-260.

Ebeling, A. M., L. G. Bundy, J. M. Powell, and T. W. Andraski. 2002. Dairy diet phosphorus effects on phosphorus losses in runoff from land-applied manure. Soil Sci. Soc. Am. J. 66:284-291.

Eghball, B., and J. F. Power. 1994. Beef cattle feedlot manure management. J. Soil Water Conserv. 49:113-132.

Ellenberger, H. B., J. A. Newlander, and C. H. Jones. 1950. Composition of the bodies of dairy cattle. Vt. Agric. Exp. Sta. Bull. 558, Univ. Vermont, Burlington.

Erickson, G. E., T. J. Klopfenstein, and C. T. Milton. 2000a. Dietary phosphorus effects on performance and nutrient balance in feedlots. Pages 10-17 in Proc. 8th Int. Symp. Animal, Agric., and Food Processing Wastes. ASAE, St. Joseph, MI.

Erickson, G. E., T. J. Klopfenstein, and C. T. Milton. 2000b. Dietary protein effects on nitrogen excretion and volatilization in opendirt feedlots. Pages 297-304 in Proc. 8th Int. Symp. Animal, Agric., and Food Processing Wastes. ASAE, St. Joseph, MI.

Erickson, G. E., T. J. Klopfenstein, C. T. Milton, D. Brink, M. W. Orth, and K. M. Whittet. 2002. Phosphorus requirement of finishing feedlot calves. J. Anim. Sci. 80:1690-1695.

Erickson, G. E., T. J. Klopfenstein, C. T. Milton, D. Hanson, and C. Calkins. 1999. Effect of dietary phosphorus on finishing steer performance, bone status, and carcass maturity. J. Anim. Sci. 77:2832-2836.

Garthwaite, B. D., C. G. Schwab, and B. K. Sloan. 1998. Amino acid nutrition of the early lactation cow. Pages 38-50 in Proc. of the Cornell Nutr. Conf. for Feed Manufacturers. Cornell Univ., Ithaca, NY.

Giger-Reverdin, S., D. Sauvant, J. Hervieu, and M. Dorleans. 1991. Fecal and urinary nitrogen losses as influenced by the diet carbohydrate and protein fractions in goats. Pages 358-360 in 6th Int. Symp. Protein Metabolism and Nutrition. Herning, Denmark.

Gilbertson, C. B., T. M. McCalla, J. R. Ellis, O. E. Cross, and W. R. Woods. 1971. Runoff, solid wastes, and nitrate movement in beef feedlots. J. Water Pollut. Control Fed. 43:483-493.

Hargrove, W. L. 1988. Evaluation of ammonia volatilization in the field. J. Prod. Agric. 1:104-111.

Hignett, S. L., and P. G. Hignett. 1951. The influence of nutrition on reproductive efficiency in cattle. I. The effect of calcium and phosphorus intake on the fertility of cows and heifers. Vet Rec. 63:603-609.

Irving, J. T. 1963. Dynamics and functions of phosphorus. Page 249 in Mineral Metabolism. vol 2. Academic Press, New York.

James, T., D. Meyer, E. Esparza, E. J. DePeters, and H. Perez-Monti. 1999. Effects of dietary nitrogen manipulation on ammonia volatilization from manure from Holstein heifers. J. Dairy Sci. 82:2430-2439.
Karn, James F. 2001. Phosphorus nutrition of grazing cattle: a review. Anim. Feed Sci. Technol. 89:133-153.

Kellems, R., J. R. Miner, and D. C. Church. 1979. Effect of ration on waste composition and length of storage on the volatilization of ammonia, hydrogen sulfide and odors from cattle waste. J. Anim. Sci. 48:436-445.

Knowlton, K. F., J. H. Herbein, M. A. Meister-Weisbarth, and W. A. Wark. 2001. Nitrogen and phosphorus partitioning in lactating Holstein cows fed different sources of dietary protein and phosphorus. J. Dairy Sci. 84:1210-1217.

Kohn, R. A., Z. Dou, J. D. Ferguson, and R. C. Boston. 1997. A sensitivity analysis of nitrogen losses from dairy farms. J. Environ. Manag. 50:417-428.

Komaragiri, M. V. S., and R. A. Erdman. 1997. Factors affecting body tissue mobilization in early lactation dairy cows. 1. Effect of dietary protein on mobilization of body fat and protein. J. Dairy Sci. 80:929-937.

Korevaar, H. 1992. The nitrogen balance on intensive Dutch dairy farms: a review. Livest. Prod. Sci. 31:17-27.

Kröber, T. F., D. R. Kulling, H. Menzi, F. Sutter, and M. Kreuzer. 2000. Quantitative effects of feed protein reduction and methionine on nitrogen use by cows and nitrogen emissions from slurry. J. Dairy Sci. 83:2941-2951.

Larson, E. M. 1992. Corn Byproducts for Finishing Cattle. M.S. thesis, Univ. Nebraska, Lincoln.

Long, T. A., A. D. Tillman, A. B. Nelson, B. Davis, and W. D. Gallup. 1956. Dicalcium phosphate and soft phosphate with colloidal clay as sources of phosphorus for beef heifers. J. Anim. Sci. 15:1112-1118.

Long, T. A., A. D. Tillman, A. B. Nelson, W. D. Gallup, and B. Davis. 1957. Availability of phosphorus in mineral supplements for beef cattle. J. Anim. Sci. 16:444-450.

Luchini, N. D., G. A. Broderick, R. E. Muck, N. F. Makoni, and R. L. Vetter. 1997. Effect of storage system and dry matter content on the composition of alfalfa silage. J. Dairy Sci. 80:1827-1832.

McCrory, D. F., and P. J. Hobbs. 2001. Additives to reduce ammonia and odor emissions from livestock wastes: A review. J. Environ. Qual. 30:345-355.

Merchen, N. R. 1993. Digestion, absorption, and excretion in ruminants. Pages 172-201 in The Ruminant Animal: Digestive Physiology and Nutrition. D. C. Church, ed. Waveland Press, Inc., Prospect Hills, IL.

Mobley, H. C. T., M. D. Island, and R. P. Hansinger. 1995. Molecular biology of microbial ureases. Microbiol. Rev. 59:451-480.

Muck, R. E., and B. K. Richards. 1980. Losses of manurial nitrogen in free stall barns. Agric. Manure 7:65-93.

NRC. 1989. Nutrient Requirements of Dairy Cattle. 6th rev ed. Natl. Acad. Press, Washington, DC.

NRC. 1996. Nutrient Requirements of Beef Cattle. 7th rev ed. Natl. Acad. Press, Washington, DC.

NRC. 2001. Nutrient Requirements of Dairy Cattle. 7th rev ed. Natl. Acad. Press, Washington, D.C.

Nebraska Agricultural Statistics Service. 2000. Nebraska Agricultural Statistics. Nebraska Department of Agriculture, in cooperation with U.S.D.A., Lincoln.

Oba, M., and M. S. Allen. 1999. Effects of brown midrib 3 mutation in corn silage on dry matter intake and productivity of high yielding dairy cows. J. Dairy Sci. 82:135-142.

Paul, J. W., N. E. Dinn, T. Kannangara, and L. J. Fisher. 1998. Protein content in dairy cattle diets affects ammonia losses and fertilizer nitrogen value. J. Environ. Qual. 27:528-534.

Raboy, V., and P. Gerbasi. 1996. Genetics of myo-inositol phosphate synthesis and accumulation. Pages 257-285 in Subcellular Biochemistry: MyoInositol Phosphate, Phosphoinositides, and Signal Transduction. vol. 26. Plenum Press, New York.

Sansinena, M., L. D. Bunting, S. R. Stokes, and E. R. Jordan. 1999. A survey of trends and rationales for phosphorus recommendations among Mid-South nutritionists. Pages 51-54 in Proc. Mid-South Ruminant Nutr. Conf. Dallas, TX.

Satter, L. D., H. G. Jung, A. M. van Vuuren, and F. M. Engels. 1999. Challenges in the nutrition of high-producing ruminants. Pages 
609-646 in Nutritional Ecology of Herbivores. Proc. 5th Int. Symp. Nutr. of Herbivores. H. G. Jung and G. C. Fahey, Jr., ed. Am. Soc. Anim. Sci., Savoy, IL.

Sloan, B. K., B. D. Garthwaite, and C. G. Schwab. 1998. Practical formulation of dairy cow diets for digestible amino acids to improve nitrogen efficiency and the bottom line. Pages 51-61 in Proc. of the Cornell Nutr. Conf. for Feed Manufacturers. Cornell Univ., Ithaca, NY.

Smits, M. C. J., H. Valk, G. J. Monteny, and A. M. van Vuuren. 1997. Effect of protein nutrition on ammonia emission from cow houses. Pages 101-107 in Gaseous Nitrogen Emissions from Grasslands. S. C. Jarvis and B. F. Pain, ed. CAB International, Wallingford, Oxon 0X10 8DE U.K.

Spears, J. W. 1996. Optimizing mineral levels and sources for farm animals. Pages 259-275 in Nutrient Management of Food Animals to Enhance and Protect the Environment. E. T. Kornegay, ed. CRC Press, Boca Raton, FL.

Tamminga, S. 1992. Nutrition management of dairy cows as a contribution to pollution control. J. Dairy Sci. 75:345-357.

Ternouth, J. H. 1990. Phosphorus and beef production in northern Australia. 3. Phosphorus in cattle-a review. Trop. Grassl. 24:159-169.

Theiler, A., and H. H. Green. 1932. Aphosphorosis in ruminants. Nutr. Abstr. Rev. 1:359-385.

Tillman, A. D., J. R. Brethour, and S. L. Hansard. 1959. Comparative procedures for measuring the phosphorus requirement of cattle. J. Anim. Sci. 18:249-255.

Tine, M. A., K. R. McLeod, R. A. Erdman, and R. L. Baldwin. 2001. Effects of brown midrib corn silage on the energy balance of dairy cattle. J. Dairy Sci. 84:885-895.
Underwood, E. J., and N. F. Suttle. 1999. The Mineral Nutrition of Livestock. Food and Agricultural Organization of the United Nations. CABI Publishing, Wallingford, Oxon, UK.

Valk, H., and L. B. J. Ebek. 1999. Influence of prolonged feeding of limited amounts of phosphorus on dry matter intake, milk production, reproduction and body weight of dairy cows. J. Dairy Sci. 82:2157-2163.

Varel, V. H., J. A. Nienaber, and H. C. Freetly. 1999. Conservation of nitrogen in cattle feedlot waste with urease inhibitors. J. Anim. Sci. 77:1162-1168.

Wadsworth, J. C., and R. D. H. Cohen. 1976. Phosphorus utilization by ruminants. Pages 143-153 in Prospects for Improving Efficiency of Phosphorus Utilization. Reviews in Rural Science. vol 1. Univ. New England Press, Australia.

Wilkerson, V. A., D. R. Mertens, and D. P. Casper. 1997. Prediction of excretion of manure and nitrogen by Holstein dairy cattle. J. Dairy Sci. 80:3193-3204.

Wise, J. B., S. E. Smith, and L. L. Barnes. 1958. The phosphorus requirement of calves. J. Anim. Sci. 17:89-99.

Wu, Z., and L. D. Satter. 2000. Milk production during the complete lactation of dairy cows fed diets containing different amounts of protein. J. Dairy Sci. 83:1042-1051.

Wu, Z., L. D. Satter, A. J. Blohowiak, R. H. Stauffacher, and J. H. Wilson. 2001. Milk production, estimated phosphorus excretion, and bone characteristics of dairy cows fed different amounts of phosphorus for two or three years. J. Dairy Sci. 84:1738-1748.

Wu, Z., L. D. Satter, and R. Sojo. 2000. Milk production, reproductive performance, and fecal excretion of phosphorus by dairy cows fed three amounts of phosphorus. J. Dairy Sci. 83:1028-1041. 